\title{
Article \\ Geomorphological and Statistical Assessment of Tilt-Block Tectonics in the Garhwal Synform: Implications for the Active Tectonics, Garhwal Lesser Himalaya, India
}

\author{
Ashish Rawat ${ }^{1,2, *(\mathbb{D}}$, Sayandeep Banerjee ${ }^{2, *}$ and Yaspal Sundriyal ${ }^{1, *}$ \\ 1 Department of Geology, Hemvati Nandan Bahuguna Garhwal University, Srinagar Garhwal 246174, India \\ 2 Centre of Advanced Study in Geology, Banaras Hindu University, Varanasi 221005, India \\ * Correspondence: ashishgeo123@gmail.com (A.R.); sayandeep87.geo@bhu.ac.in (S.B.); \\ ypsundriyal@gmail.com (Y.S.); Tel.: +91-9412079912 (Y.S.)
}

\section{check for}

updates

Citation: Rawat, A.; Banerjee, S.; Sundriyal, Y. Geomorphological and Statistical Assessment of Tilt-Block Tectonics in the Garhwal Synform: Implications for the Active Tectonics, Garhwal Lesser Himalaya, India. Geosciences 2021, 11, 345. https:/ / doi.org/10.3390/geosciences11080345

Academic Editors: Ioannis

Koukouvelas, Jesus Martinez-Frias, Riccardo Caputo and Tejpal Singh

Received: 4 July 2021

Accepted: 7 August 2021

Published: 18 August 2021

Publisher's Note: MDPI stays neutral with regard to jurisdictional claims in published maps and institutional affiliations.

Copyright: (c) 2021 by the authors. Licensee MDPI, Basel, Switzerland. This article is an open access article distributed under the terms and conditions of the Creative Commons Attribution (CC BY) license (https:// creativecommons.org/licenses/by/ $4.0 /)$.

\begin{abstract}
Active tectonics is manifested in geomorphological features such as drainage basins and drainage patterns. Geomorphic parameters asymmetry factor $(A F)$ and transverse topography symmetry factor $(T)$ is calculated for 94 third order basins of the Garhwal synform to decipher the tilt-block tectonics based on remote sensing and geographical information system (GIS) techniques. The quantitative analysis of the $A F$ suggests that all the 94 basins are asymmetric and gentle to steeply tilted, indicating active tectonics and early and late stage of development, respectively. The mean vector magnitude $\left(\theta_{v}\right)$ of $T$ suggests the migration of the basin stream towards the south in most basins $(60 \%)$, suggesting a unidirectional tilting of the tectonic block. The $\chi^{2}$ test for statistical significance indicates that the $\theta_{v}$ is significant for southern and northern limb basins. The $\chi^{2}$ test affirms that the third order basin position on either side of the main channel of the river basin influences the tilt direction. The regional tectonics suggests migration of the Lansdowne klippe towards the south, as the majority of third order basins show southward tilt. The study provides a quick appraisal of tilting in the tectonic blocks of active margins, such as in the Himalayas.
\end{abstract}

Keywords: Himalaya; Garhwal synform; geomorphic parameters; tilt-block tectonics; active tectonics; remote sensing

\section{Introduction}

The Himalaya is formed as a result of the inter-continental collision between the Indo and Eurasian plates. The continuous northward movement of the Indian plate resulted in increased seismic activity in the Himalayan region. The convergence of tectonic plates has resulted in crustal shortening, formation of fault/thrusts and active tectonics in the Himalaya [1]. The movement of hanging wall material over its footwall in the Himalaya has resulted in the migration of tectonic blocks towards the south. The movement of tectonic blocks due to active tectonic activities in the Himalaya is predominant, confirmed by earlier studies [2], suggesting a convergence rate of 10-15 mm/year and a slip rate of $13.8 \pm 3.6 \mathrm{~mm} /$ year. Other reports on active tectonics [3] suggest a convergence rate of $10.79 \pm 2.23 \mathrm{~mm} /$ year, slip rate of $12.46 \pm 2.58 \mathrm{~mm} /$ year, and uplift rate of $6.23 \pm 1.29 \mathrm{~mm} /$ year in the Dun region of Garhwal Himalaya and Kala Amb of Himachal Pradesh and [4] proposed a movement of $15 \mathrm{~mm} /$ year across the Kumaun-Garhwal Himalaya.

Several authors envisage that the movement of tectonic blocks influences the geomorphology of the Earth's surface and the development of drainage networks [5-7]. Additionally, the movement of tectonic blocks along faults has resulted in active tectonic activities in an area, and in turn, controls the behavior and development of drainage features [8]. Geomorphic features are the manifestations of the landscape evolution of a basin and thus are often utilized for the quantitative and qualitative assessment of tectonic 
activity $[9,10]$. Geomorphic indices, asymmetry factor $(A F)$ and transverse topography symmetry factor $(T)$ are the parameters chosen to investigate the relationship between tectonics and morphology of drainage basins in the present work.

The tilting of tectonic blocks is a reliable expression to detect the dynamics of crustal deformation. Earlier studies, based upon the tilting of tectonic blocks coupled with geomorphic characteristics of litho-units across the globe, have helped to decipher the active crustal deformation in fold-thrust belts [5,11-13]. It is also proposed that tilting due to tectonic activity, resulting in the gradient change, might influence the drainage system of rivers [14]. Usually, drainages respond to tectonic tilting by migrating to a down tilting direction, which gets preserved as the favorable direction of the drainage basin transverse asymmetry in the tectonically tilted region [7].

Geographical or natural barriers and government restrictions enforced in and surrounding regions of Garhwal synform pose limitations in field-based studies. Thus, no detailed research related to tectonic block tilting has yet been done in the area. Efficient modern tools can counter challenges related to such situations as Remote Sensing and Geographic Information System (GIS) provide accurate and reliable information quickly. Using satellite imagery to detect geomorphological features due to tectonic tilting has become a common practice [7,15-17] in India and elsewhere. While several studies related to structure, stratigraphy, hydrology, etc. [18-24], has been carried out in parts of the Garhwal synform, a detailed account of the role of active tectonics in hydrological characteristics, tilt-block tectonics, and geomorphology is yet to be narrated from the study area. The present study emphasizes on addressing the above gaps in knowledge by using geomorphic parameters coupled with remote sensing and GIS techniques. The down-tilting of third order basins also indicate the impact of regional and local geological structures; therefore, the down-tilt data can be used to evaluate active tectonics in the study area. Thus, the objective of the current work is to ascertain the active tectonics operating in the Garhwal synform by evaluating the tilting of third order basins. The study also accounts for the geomorphology, upliftment, and information on the migration of Lesser Himalaya tectonic block in the Garhwal synform.

The study area lies in the NW-SE trending Garhwal synform of the Lesser Himalaya region of the Garhwal Himalaya in the Pauri district of Uttarakhand, situated between $78^{\circ} 19^{\prime}-79^{\circ} 00^{\prime} \mathrm{E}$ and $29^{\circ} 41^{\prime}-30^{\circ} 13^{\prime} \mathrm{N}$ (Figure 1). The major river basins are Palain River, Malin River, Khoh River, Rawasan River, Hiyunl River, along with two significant tributaries Tal Nadi and Medi Gad; and form the drainage system of the Garhwal synform. Rivers in the region are predominantly rain and spring-fed. The region receives high torrential rainfall during the monsoon in June and July, leading to occasional flash floods. Physiographically, the area has high to moderately dissected mountains and fluvial plains formed by prolonged tectonics, erosion, and deposition. The study area is seismically active and is placed in seismic class 'IV' as of 9 July 2021 by the National Centre of Seismology (https:/ / seismo.gov.in, accessed on 9 July 2021). 


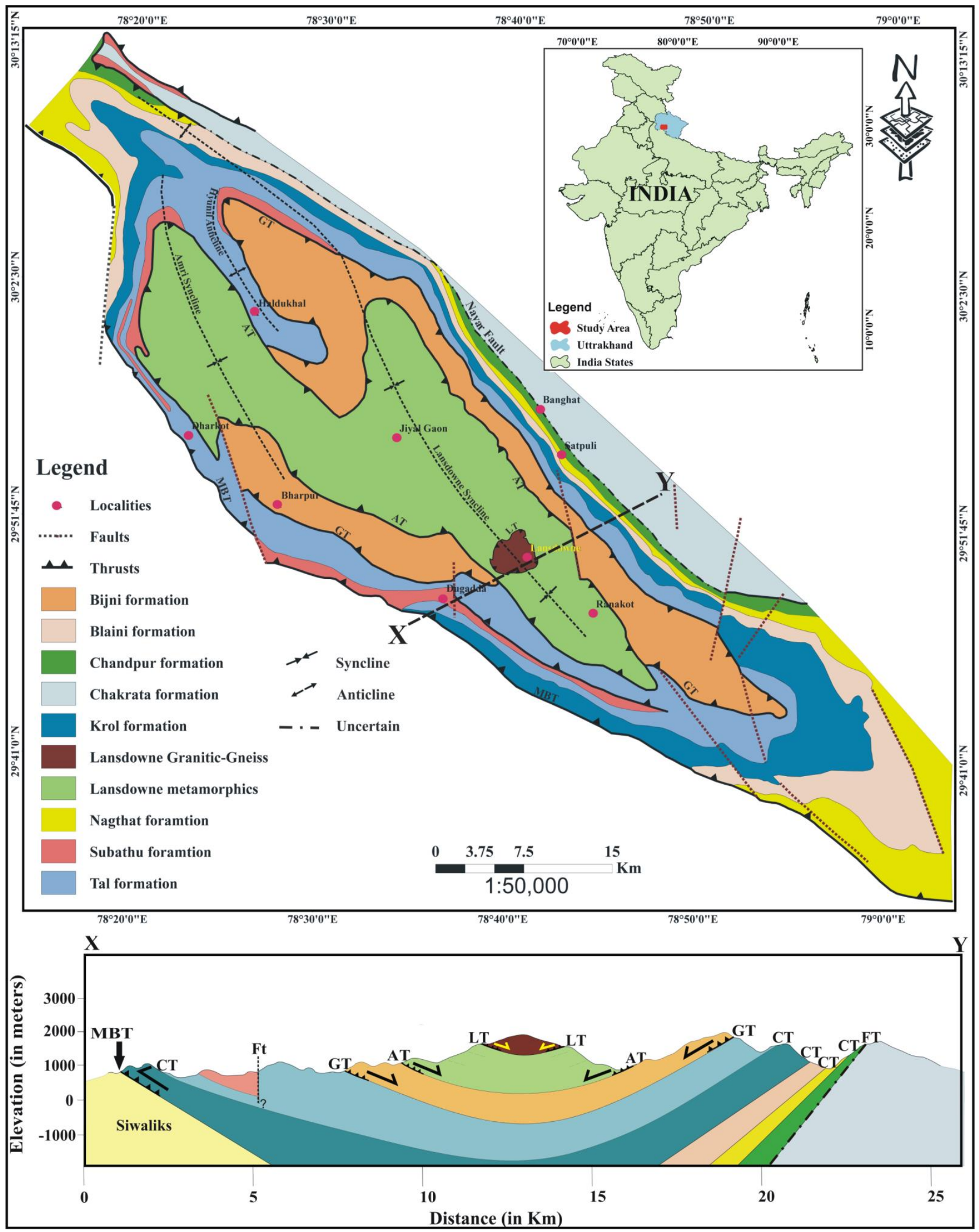

Figure 1. The location and geological map of the Garhwal synform show the lithotectonic units (after [24,25]); the X-Y 
cross-section (adapted from [17]) at the bottom shows the generalized arrangement of tectonic blocks in the Garhwal synform central (MBT = Main boundary thrust, $\mathrm{CT}=$ lithocontacts, $\mathrm{Ft}=$ Unidentified fault, $\mathrm{GT}=\mathrm{Garhwal}$ thrust, $\mathrm{AT}=\mathrm{Amri}$ thrust, $\mathrm{LT}=$ Lansdowne thrust).

\section{Geological Setting}

The Garhwal synform comprises of metamorphic rocks of the Lesser Himalaya (Mesoproterozoic to Proterozoic age), sedimentary rocks of Siwalik Himalaya (Neoproterozoic to Eocene age) and Holocene alluvial deposits of Indo-Gangetic Plain $[18,25,26]$. The Lesser Himalaya lies between two tectonic planes in the Garhwal region, the Main Central Thrust $(\mathrm{MCT})$, in the north and the Main Boundary Thrust (MBT) in the south $[27,28]$. The lithology of the rocks in the study area includes Lesser Himalayan meta-sediments separated by NW-SE trending MBT from the Siwaliks; further south, the Himalayan frontal thrust (HFT) separates the Siwalik Sedimentary Sequence from the alluvium of the Indo Gangetic Plains (IGP) [25,29]. Several mesoscale thrusts, viz. Amri thrust, Garhwal thrust, Lansdowne thrust, etc. $[29,30]$ dissect the river basins in the Garhwal synform (Figure 1).

The Garhwal synform of the Lesser Garhwal Himalaya sequence exhibits complex and intricate geology due to polyphase deformation. The rocks in the study area were subjected to superposed folding, faulting, and thrusting, resulting in a complex stratigraphy and are grouped into several litho-tectonic units [27,31-34]. The southern part of the Garhwal synform has been studied in detail to elucidate the structural setup of the region [19-23,35]. Tectonically the lowermost unit of the Garhwal Nappe is the Bijni formation composed of quartzite-phyllite sequence in the lower horizon that grade into quartzite-schist sequence upwards; it overlies the sedimentary rocks of Krol Nappe along with Garhwal thrust (Figure 1). The Bijni formation [32] is tectonically overthrusted by the Lansdowne Metamorphic Formation along with the Amri thrust [25] and has also been described as Lansdowne Metamorphics [20,21] and Lansdowne crystallines [25] (Figure 1). It is mainly composed of phyllite and schist with prominent deformational structures like folds, joints, fractures, boudins, etc. The Garhwal Nappe is tectonically capped by a small basinal structure of the Lansdowne Granite Gneiss across the Lansdowne thrust [36], having mylonitized gneiss at the base that progressively grades to augen gneiss and gneissic granite (Figure 1) towards the top [21].

\section{Material and Methods}

Here, all the third order basins of the Garhwal synform are considered under investigation for gauging the possible tilt using geomorphic parameters. The third order basins are chosen over the first, and second order basins because the first and second order basins can be influenced by vegetation, lithology, topography, stream-flow variation or stream discharge, etc. $[6,13,37]$. In contrast, the third order streams show a significant change in their behavior due to active tectonics [13]. This study quantified only third order drainage basins in the Garhwal synform region having an area of $>2 \mathrm{~km}^{2}$. Subsequently, we calculated the asymmetry factor $(A F)$ and transverse topography symmetry factor $(T)$ for a total of 94 third order drainage basins. The drainage and basins were delineated using SRTM30 DEM 1 arc-second (Shuttle Radar Topographic Mission- Digital elevation model) in GIS platform by requisite hydrological tools. Furthermore, the extracted drainages and watershed boundaries were superimposed over the Survey of India toposheet on 1:50,000, scale and ortho-corrected IRSP-LISS-III (Indian Remote Sensing ProgrammeLinear Integrated Self-Scanning Sensor) image from the Indian Remote Sensing Satellite for minor adjustments.

According to several studies carried out in the different parts of the world, $A F$ and $T$ have proven to be influential in determining active ground tilting [5-7,38-43]. Both $A F$ and $T$ indices assess the preferred lateral shifting of the trunk stream of a drainage basin to the basin margin or drainage divide (Figure 2a,b). It indicates that even a small lateral shifting with the tectonic tilt can facilitate incision and head-ward erosion of streams [44]. The tectonic tilting lengthens the up-tilted tributaries shifting the drainage divide in the 
up-tilt direction and pushing the trunk stream in the down-tilt direction due to increased sediment delivery and accumulation by tributaries of the up-tilted side of the basin [5].

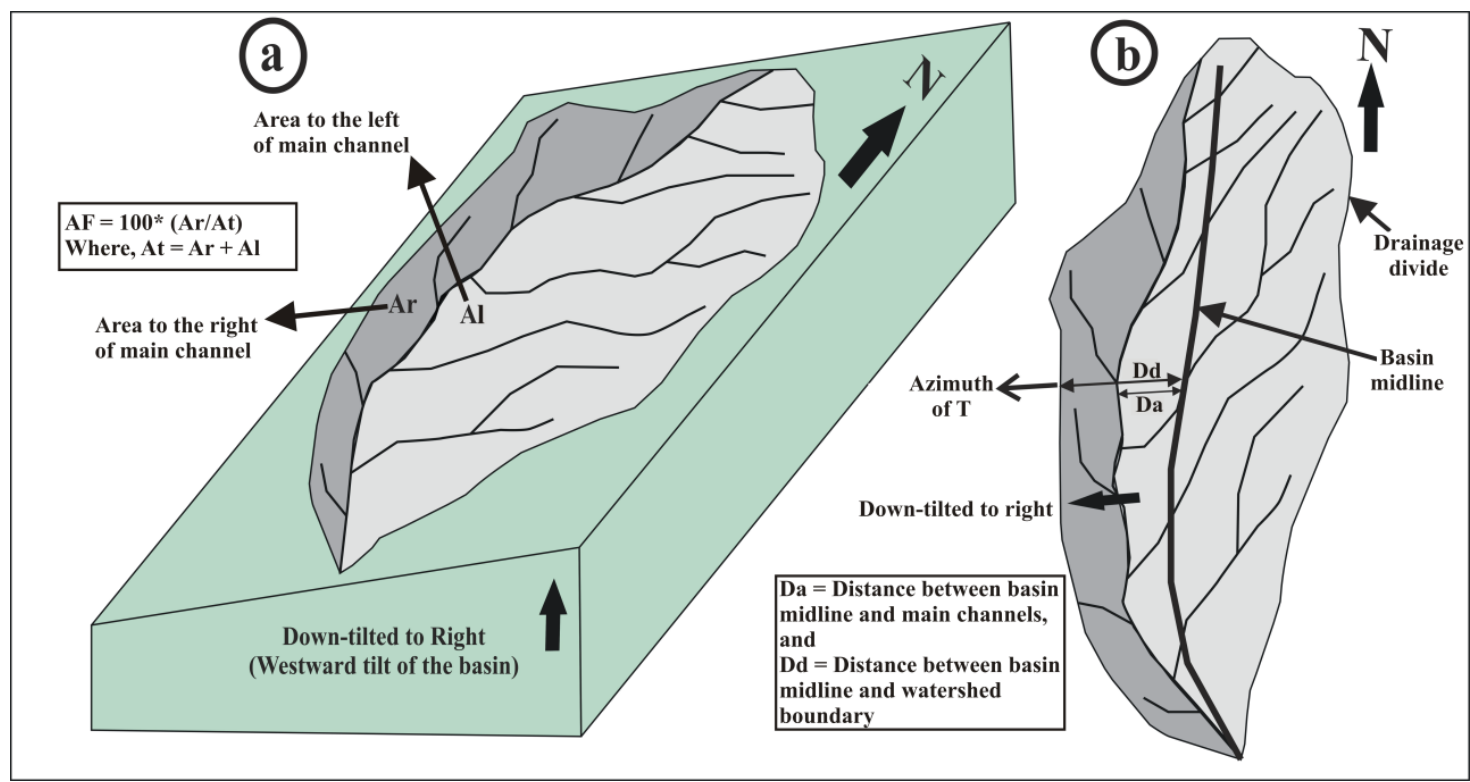

Figure 2. Schematic diagram (a) showing Asymmetry Factor $(A F)$, tilt direction in the tectonic block and variability in the area to the right and left of trunk stream; (b) Transverse topography symmetry factor $(T)$ azimuth direction and down-tilt direction and essential component to calculate basin $T$ (adapted after [13]).

The $A F$ examines whether the areas to the left and right of a drainage basins trunk stream are placed symmetrically [5]. It is mathematically expressed as

$$
A F=100 *\langle A r / A t\rangle
$$

where $A r$ is the area to the right of its trunk stream in the downstream direction, and $A t$ is the total area of a drainage basin (Figure 2a). An $A F$ value equal to 50 indicates that the sites to the left and right of the basin's trunk stream are symmetrically placed and thus suggests tectonic stability during the basin development. Alternatively, any deviation from the $A F$ value of 50 indicates that the areas to the left and right of the basin's trunk stream are asymmetrically placed and suggests basin development on tilted blocks. $A F$ values of $<50$ or $>50$ indicate rightward or leftward down-tilting of the trunk stream, respectively $[45,46]$. The more significant is the deviation from 50; the steeper is the basin's tilting [40]. We translated the rightward and leftward down-tilting directions into four broad azimuth classes of N, E, S, and W (similar to Figure 2a); we chose only four azimuth classes to accommodate all inherent randomness in the overall down-tilting of the basins. The frequency distribution of azimuth classes is then used to infer random or preferential stream migration in the outlined area. The reliability of the inference was ascertained by subjecting the data to the Chi-square $\left(\chi^{2}\right)$ test of statistical significance [47]. The $\chi^{2}$ is mathematically expressed as

$$
\chi^{2}=\frac{\sum_{J=1}^{n}\left(O_{j}-E_{j}\right)^{2}}{E_{j}}
$$

where $O_{j}$ and $E_{j}$ are the expected and observed number of data in class $j$ respectively.

On the other hand, the transverse topographic symmetry factor $(T)$ examines if the trunk stream of a drainage basin has laterally migrated from the basin axis due to subtle changes in the tectonic framework $[45,48]$. Thus, it can be used as a proxy to assess the 
small-scale basin disturbances like faults, lithocontacts, shear zones, etc. due to tectonic activity and is mathematically expressed as

$$
T=D a / D d
$$

Here $D a$ is the distance from the midline of the river basin to the midline of the active channel, and $D d$ is the distance from basin midline to basin divide [48] (Figure 2b). $T$ is a symmetry factor, so its value indicates tilt in the basin due to deformation; its value ranges from zero to one $(T=0-1)$. The lower value $(T=0)$ represents a perfectly symmetric basin, and the higher value $(T>0)$ suggests asymmetry in the basin; the higher the value more will be the asymmetry or higher will be the basin tilt $[9,10,48,49]$.

The value of $T$ is a vector quantity and is calculated at different segments taken at equal intervals of a stream. Arithmetic average is computed of these segments down-tilt magnitude and vector mean of azimuths to calculate magnitude and direction of downtilt for the basins [48]; the greater is the magnitude of $T$; the steeper is the basins tilting. Subsequently, the arithmetic average of all the drainage basins down-tilt magnitude and mean vector azimuth and vector magnitude of their azimuths were used to decipher the outlined area's tilting. The vector mean of down-tilting azimuths $\left(\bar{\theta}_{v}\right)$ was computed using the formula $[47,48]$

$$
\bar{\theta}_{v}=\tan ^{-1}\left(\frac{\sum_{1}^{n} \sin \theta}{\sum_{1}^{n} \cos \theta}\right)
$$

while the mean vector magnitude $(r)$ is calculated using the formula

$$
r=\frac{1}{n} \sqrt{\left[\left(\sum_{1}^{n} \sin \theta\right)^{2}+\left(\sum_{1}^{n} \cos \theta\right)^{2}\right]}
$$

where $\theta$ is the azimuth of a vector and $n$ is the number of azimuth vectors averaged [47]. The statistical significance of these results was ascertained by calculating the probability $(p)$ of obtaining a greater mean vector magnitude by chance combination of random vectors [50]. It is mathematically expressed as

$$
p=e^{\left(-L^{2} n\right)\left(10^{-4}\right)}
$$

where $L$ is the mean vector magnitude $(r)$ multiplied by 100 , and $\mathrm{n}$ is the number of vectors averaged. We placed the upper threshold value of $p$ as 0.5 for significance to accommodate inherited randomness as suggested by [5].

\section{Results}

\subsection{Drainage Characteristics}

The Garhwal synform is drained by five major river basins and two tributary streams. The Palain, Malin, Rawasan, Khoh, and Hiyunl rivers are 6th order streams, while the two tributaries Tal Nadi and Medi Gad, are fifth order streams. The Palain river drains about $19.76 \mathrm{Km}$ area in the NW-SE direction, Malin River flows E-SW and drains $40.84 \mathrm{~km}$, and Khoh River flows in NE-SW and drains $36.8 \mathrm{~km}$. Similarly, Rawasan River is trending NE-SW and flows up to $34.5 \mathrm{~km}$, Hiyunl River is flowing SE-NW direction covers $40.79 \mathrm{~km}$. Additionally, two other fifth order streams also contribute to the drainage system of the Garhwal synformal region; Tal Nadi is trending SE-NW travelling for $16.4 \mathrm{~km}$, and Medi Gad, which is also the smallest catchment flows SE to NW for $13.8 \mathrm{~km}$ (Figure 3). The higher-order streams show several geomorphic features like abrupt deflection and associated straight course at places, suggesting structural antecedents. All the rivers flow through highly dissected hills ranging from broad valleys to narrow gorges in the region. All the geomorphic features formed by the rivers and their stream course indicate tectonic influence on drainage characteristics. 


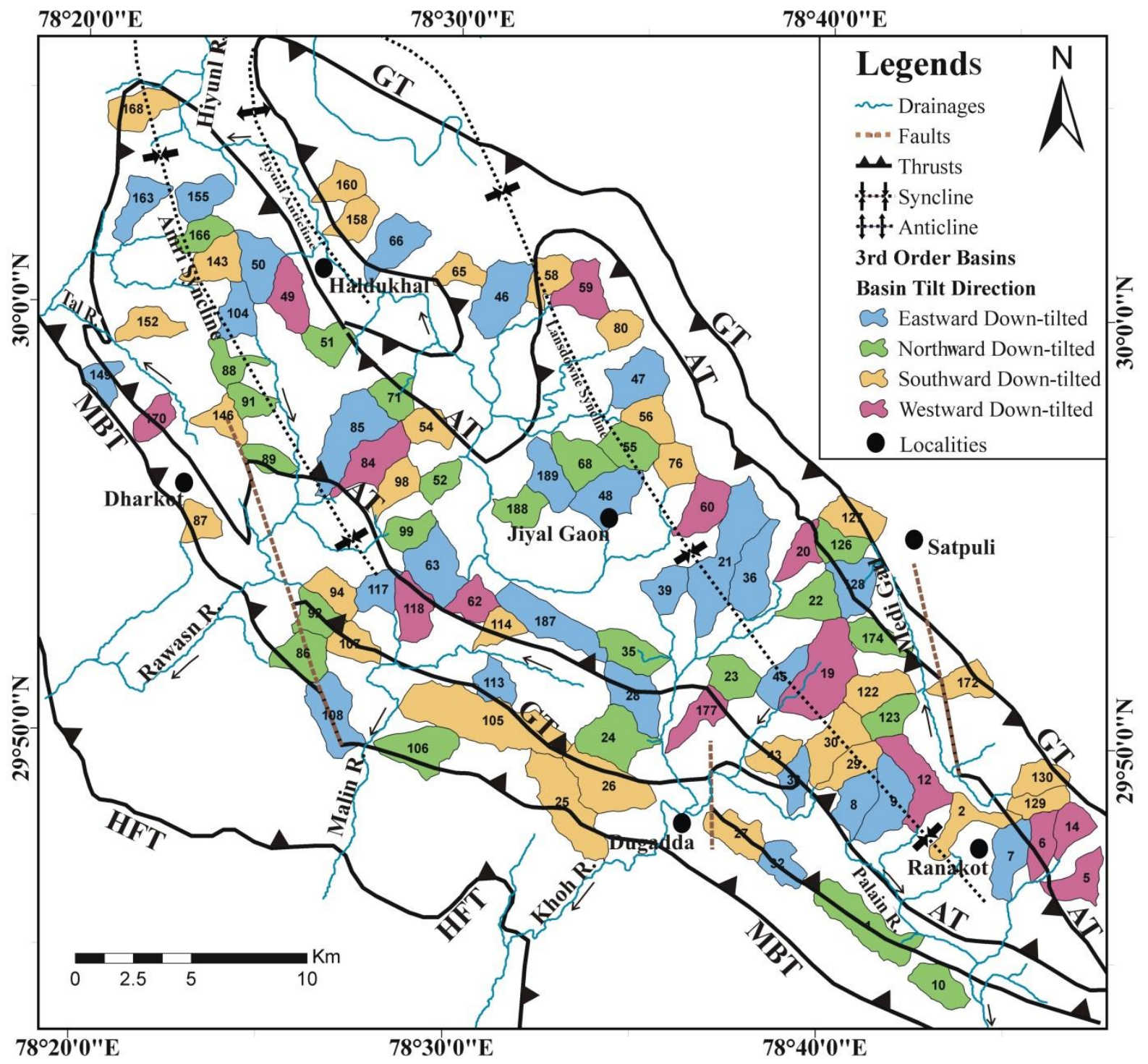

Figure 3. Map showing the down-tilt directions of third order basins from both northern and southern limbs of Garhwal synform. Black arrows indicate river flow direction, while numbers on each third order basin are Basin IDs, as shown in Table 1. Several structural entities of synform viz. thrust, faults, syncline and anticline are shown in the map.

Table 1. Geomorphic parameters calculated for both the northern and southern limb of the Garhwal synform.

\begin{tabular}{|c|c|c|c|c|c|}
\hline \multirow{2}{*}{ Basin No. } & \multicolumn{2}{|r|}{$A F$} & \multicolumn{2}{|r|}{$T$} & \multirow{2}{*}{ Zone } \\
\hline & Value & Down-Tilt Direction & Mean Magnitude of $T$ & Vector mean of $T$ Azimuths & \\
\hline 1 & 67.949 & $\mathrm{~N}$ & 0.97 & $\mathrm{~N} 37^{\circ}$ & \multirow{9}{*}{$\begin{array}{l}\text { Southern } \\
\text { Limb }\end{array}$} \\
\hline 2 & 60.618 & $S$ & 0.30 & $\mathrm{~N} 225^{\circ}$ & \\
\hline 5 & 20.334 & $\mathrm{~W}$ & 0.89 & $\mathrm{~N} 256^{\circ}$ & \\
\hline 6 & 44.908 & $\mathrm{~W}$ & 0.45 & N194 $4^{\circ}$ & \\
\hline 7 & 59.585 & E & 0.56 & $\mathrm{~N} 137^{\circ}$ & \\
\hline 8 & 57.66 & E & 0.56 & $\mathrm{~N} 143^{\circ}$ & \\
\hline 9 & 62.4 & E & 0.83 & $\mathrm{~N} 108^{\circ}$ & \\
\hline 10 & 57.986 & $\mathrm{~N}$ & 0.60 & $\mathrm{~N} 54^{\circ}$ & \\
\hline 12 & 44.572 & $\mathrm{~W}$ & 0.88 & $\mathrm{~N} 249^{\circ}$ & \\
\hline
\end{tabular}


Table 1. Cont.

\begin{tabular}{|c|c|c|c|c|c|}
\hline \multirow{2}{*}{ Basin No. } & \multicolumn{2}{|r|}{$A F$} & \multicolumn{2}{|r|}{$T$} & \multirow{2}{*}{ Zone } \\
\hline & Value & Down-Tilt Direction & Mean Magnitude of $T$ & Vector mean of $T$ Azimuths & \\
\hline 14 & 31.719 & $\mathrm{~W}$ & 0.57 & $\mathrm{~N} 274^{\circ}$ & \\
\hline 19 & 26.165 & $\mathrm{~W}$ & 0.92 & $\mathrm{~N} 312^{\circ}$ & \\
\hline 20 & 39.149 & $\mathrm{~W}$ & 0.60 & $\mathrm{~N} 269^{\circ}$ & \\
\hline 21 & 53.664 & E & 0.59 & $\mathrm{~N} 145^{\circ}$ & \\
\hline 22 & 37.181 & $\mathrm{~N}$ & 0.59 & $\mathrm{~N} 302^{\circ}$ & \\
\hline 23 & 48.525 & $\mathrm{~N}$ & 0.63 & $\mathrm{~N}^{\circ} 2^{\circ}$ & \\
\hline 24 & 49.979 & $\mathrm{~N}$ & 0.60 & $\mathrm{~N} 314^{\circ}$ & \\
\hline 25 & 30.634 & $\mathrm{~S}$ & 0.93 & $\mathrm{~N} 233^{\circ}$ & \\
\hline 26 & 48.81 & $S$ & 0.93 & $\mathrm{~N} 216^{\circ}$ & \\
\hline 27 & 55.872 & $S$ & 0.59 & $\mathrm{~N} 167^{\circ}$ & \\
\hline 28 & 66.415 & $\mathrm{E}$ & 0.93 & $\mathrm{~N} 53^{\circ}$ & \\
\hline 29 & 64.978 & $S$ & 0.62 & $\mathrm{~N} 183^{\circ}$ & \\
\hline 30 & 61.426 & $S$ & 0.15 & $\mathrm{~N} 204^{\circ}$ & \\
\hline 32 & 34.64 & $E$ & 0.68 & N94 ${ }^{\circ}$ & \\
\hline 33 & 62.771 & $E$ & 0.99 & N98 ${ }^{\circ}$ & \\
\hline 35 & 65.468 & $\mathrm{~N}$ & 0.96 & $\mathrm{~N} 89^{\circ}$ & \\
\hline 36 & 61.851 & $\mathrm{E}$ & 0.58 & $\mathrm{~N} 145^{\circ}$ & \\
\hline 39 & 43.749 & $E$ & 0.97 & $\mathrm{~N} 175^{\circ}$ & \\
\hline 43 & 55.059 & $S$ & 0.23 & N195 & \\
\hline 45 & 70.353 & $\mathrm{E}$ & 0.97 & $\mathrm{~N} 125^{\circ}$ & \\
\hline 105 & 53.165 & $S$ & 0.20 & $\mathrm{~N} 121^{\circ}$ & \\
\hline 106 & 29.166 & $\mathrm{~N}$ & 1.00 & N353 & \\
\hline 107 & 40.869 & $S$ & 0.61 & N158 & \\
\hline 108 & 68.726 & $\mathrm{E}$ & 0.86 & $\mathrm{~N} 57^{\circ}$ & \\
\hline 113 & 26.429 & $E$ & 0.96 & $\mathrm{~N} 66^{\circ}$ & \\
\hline 114 & 61.126 & $S$ & 0.60 & $\mathrm{~N} 177^{\circ}$ & \\
\hline 117 & 67.052 & $\mathrm{E}$ & 0.85 & $\mathrm{~N} 87^{\circ}$ & \\
\hline 118 & 39.39 & W & 0.64 & $\mathrm{~N} 243^{\circ}$ & \\
\hline 122 & 42.857 & $S$ & 0.56 & $\mathrm{~N} 204^{\circ}$ & \\
\hline 123 & 50.344 & $\mathrm{~N}$ & 0.59 & $\mathrm{~N} 296^{\circ}$ & \\
\hline 126 & 75.719 & $\mathrm{~N}$ & 0.69 & $\mathrm{~N} 57^{\circ}$ & \\
\hline 127 & 45.66 & $S$ & 0.29 & $\mathrm{~N} 172^{\circ}$ & \\
\hline 128 & 31.077 & $E$ & 0.98 & $\mathrm{~N} 129^{\circ}$ & \\
\hline 129 & 56.987 & $S$ & 0.60 & $\mathrm{~N} 132^{\circ}$ & \\
\hline 130 & 65.434 & $S$ & 0.96 & $\mathrm{~N} 165^{\circ}$ & \\
\hline 172 & 64.438 & $S$ & 0.57 & $\mathrm{~N} 212^{\circ}$ & \\
\hline 174 & 63.392 & $\mathrm{~N}$ & 0.99 & $\mathrm{~N} 17^{\circ}$ & \\
\hline 177 & 30.17 & W & 0.98 & $\mathrm{~N} 316^{\circ}$ & \\
\hline
\end{tabular}


Table 1. Cont.

\begin{tabular}{|c|c|c|c|c|c|}
\hline \multirow{2}{*}{ Basin No. } & \multicolumn{2}{|r|}{$A F$} & \multicolumn{2}{|r|}{$T$} & \multirow{2}{*}{ Zone } \\
\hline & Value & Down-Tilt Direction & Mean Magnitude of $T$ & Vector mean of $T$ Azimuths & \\
\hline 46 & 77.27 & E & 0.99 & $\mathrm{~N} 128^{\circ}$ & \multirow{38}{*}{$\begin{array}{l}\text { Northern } \\
\text { Limb }\end{array}$} \\
\hline 47 & 61.68 & E & 0.97 & $\mathrm{~N} 130^{\circ}$ & \\
\hline 48 & 51.65 & $\mathrm{E}$ & 0.90 & $\mathrm{~N} 113^{\circ}$ & \\
\hline 49 & 51.15 & $\mathrm{~W}$ & 0.98 & $\mathrm{~N} 258^{\circ}$ & \\
\hline 50 & 32.29 & E & 0.86 & $\mathrm{~N} 116^{\circ}$ & \\
\hline 51 & 53.04 & $\mathrm{~N}$ & 0.61 & $\mathrm{~N} 304^{\circ}$ & \\
\hline 52 & 54.04 & $\mathrm{~N}$ & 0.95 & $\mathrm{~N} 311^{\circ}$ & \\
\hline 54 & 31.82 & $S$ & 0.64 & $\mathrm{~N} 225^{\circ}$ & \\
\hline 55 & 33.43 & $\mathrm{~N}$ & 0.59 & $\mathrm{~N} 65^{\circ}$ & \\
\hline 56 & 62.88 & $S$ & 0.96 & $\mathrm{~N} 197^{\circ}$ & \\
\hline 58 & 68.47 & $S$ & 0.49 & $\mathrm{~N} 161^{\circ}$ & \\
\hline 59 & 43.09 & $\mathrm{~W}$ & 0.45 & $\mathrm{~N} 244^{\circ}$ & \\
\hline 60 & 34.84 & $\mathrm{~W}$ & 0.57 & $\mathrm{~N} 271^{\circ}$ & \\
\hline 62 & 56.07 & $\mathrm{~W}$ & 0.98 & $\mathrm{~N} 256^{\circ}$ & \\
\hline 63 & 65.48 & $E$ & 0.60 & $\mathrm{~N}^{2} 23^{\circ}$ & \\
\hline 65 & 70.30 & $S$ & 0.62 & $\mathrm{~N} 210^{\circ}$ & \\
\hline 66 & 63.14 & $\mathrm{E}$ & 0.97 & N135 & \\
\hline 68 & 39.57 & $\mathrm{~N}$ & 0.71 & $\mathrm{~N} 64^{\circ}$ & \\
\hline 71 & 65.63 & $\mathrm{~N}$ & 0.95 & $\mathrm{~N} 341^{\circ}$ & \\
\hline 76 & 51.17 & $S$ & 0.23 & $\mathrm{~N} 180^{\circ}$ & \\
\hline 80 & 52.95 & $S$ & 0.62 & $\mathrm{~N} 155^{\circ}$ & \\
\hline 84 & 36.13 & $\mathrm{~W}$ & 0.28 & $\mathrm{~N} 244^{\circ}$ & \\
\hline 85 & 70.29 & $\mathrm{E}$ & 0.34 & $\mathrm{~N} 135^{\circ}$ & \\
\hline 86 & 29.24 & $\mathrm{~N}$ & 0.99 & $\mathrm{~N} 351^{\circ}$ & \\
\hline 87 & 33.58 & $S$ & 0.69 & $\mathrm{~N} 204^{\circ}$ & \\
\hline 88 & 68.04 & $\mathrm{~N}$ & 0.68 & $\mathrm{~N} 55^{\circ}$ & \\
\hline 89 & 72.85 & $\mathrm{~N}$ & 0.99 & $\mathrm{~N}^{\prime} 2^{\circ}$ & \\
\hline 91 & 66.49 & $\mathrm{~N}$ & 0.99 & $\mathrm{~N} 12^{\circ}$ & \\
\hline 92 & 30.50 & $\mathrm{~N}$ & 0.99 & $\mathrm{~N} 44^{\circ}$ & \\
\hline 94 & 65.67 & $S$ & 0.95 & $\mathrm{~N} 201^{\circ}$ & \\
\hline 98 & 53.51 & $S$ & 0.21 & $\mathrm{~N} 208^{\circ}$ & \\
\hline 99 & 57.19 & $\mathrm{~N}$ & 0.60 & $\mathrm{~N} 312^{\circ}$ & \\
\hline 104 & 59.14 & E & 0.95 & $\mathrm{~N} 83^{\circ}$ & \\
\hline 143 & 63.19 & $S$ & 0.90 & $\mathrm{~N} 170^{\circ}$ & \\
\hline 146 & 69.34 & $S$ & 0.41 & $\mathrm{~N} 196^{\circ}$ & \\
\hline 149 & 33.28 & $\mathrm{E}$ & 0.95 & $\mathrm{~N} 102^{\circ}$ & \\
\hline 152 & 60.48 & $S$ & 0.27 & $\mathrm{~N} 170^{\circ}$ & \\
\hline 155 & 49.76 & $\mathrm{E}$ & 0.49 & $\mathrm{~N} 212^{\circ}$ & \\
\hline
\end{tabular}


Table 1. Cont.

\begin{tabular}{|c|c|c|c|c|c|}
\hline \multirow{2}{*}{ Basin No. } & \multicolumn{2}{|r|}{$A F$} & \multicolumn{2}{|r|}{$T$} & \multirow{2}{*}{ Zone } \\
\hline & Value & Down-Tilt Direction & Mean Magnitude of $T$ & Vector mean of $T$ Azimuths & \\
\hline 158 & 52.78 & S & 0.34 & $\mathrm{~N} 218^{\circ}$ & \\
\hline 160 & 51.24 & S & 0.19 & $\mathrm{~N} 228^{\circ}$ & \\
\hline 163 & 53.32 & E & 0.72 & $\mathrm{~N} 97^{\circ}$ & \\
\hline 166 & 38.18 & $\mathrm{~N}$ & 0.95 & $\mathrm{~N} 340^{\circ}$ & \\
\hline 168 & 44.99 & S & 0.26 & $\mathrm{~N} 168^{\circ}$ & \\
\hline 170 & 61.45 & W & 0.33 & $\mathrm{~N} 240^{\circ}$ & \\
\hline 187 & 37.79 & $\mathrm{E}$ & 0.21 & $\mathrm{~N} 106^{\circ}$ & \\
\hline 188 & 38.74 & $\mathrm{~N}$ & 0.73 & $\mathrm{~N} 326^{\circ}$ & \\
\hline 189 & 43.29 & $\mathrm{E}$ & 0.63 & $\mathrm{~N} 103^{\circ}$ & \\
\hline
\end{tabular}

The analyzed third order basins in the study area suggest a dendritic to sub-dendritic type arrangement of drainages. Similarly, the overall drainage network in the Garhwal synformal region shows dendritic, sub-dendritic and trellis type drainage patterns arranged in hierarchical order. As the lithology is mostly meta-sedimentary to metamorphic in most river basins, the rivers remove the material from valley slopes mechanically. The third order drainages do not have much vigor to remove these hard rocks and are favorable to flow over regolith; thus, the region's structural attributes do not control them. The third order basins were chosen because structural antecedents do not influence them; the change in their symmetry is possibly due to tilt in the basin, favoring the migration of streams towards the down-tilt direction. The material removed is placed mostly along mountain fronts and broad valleys. It is noticed that the stream obstructed by higher-order streams and geological structure forms fluvial terraces or fan deposits at those places. The fluvial terraces are mostly thick along ridges supporting thick vegetation cover, extensive farming and settlement in these areas. It suggests slope of the individual facet of a hill is an independent entity and is not controlled by the structural dip of the rocks. Thus, we can ascertain no impact of the structural dip on the basin in the study area (e.g., [13]). From the basin asymmetry, it is also suggested that the down-tilt directions of third order basins are not uniform and do not follow the structural dip of the litho-units in the area.

\subsection{Geomorphic Indices}

Two geomorphic indices were calculated for the 94 third order basins from the region to assess the tilt in the Garhwal synform. After quantifying the $A F$ for 94 basins, it is observed without any exception that all the basins are asymmetric in nature. The $A F$ for the 37 basins ranges from 20.3-49.9; for the remaining 47 basins, the value ranges from 50.3-77.3 (Table 1). Thus, in 37 basins of the study area left flank of the trunk stream occupy 0.1 to $29.7 \%$ of the larger area, while in the remaining 47 basins, it occupies $0.3-27.3 \%$ larger area to the right of the trunk stream (Figure 3). Similarly, the down tilt may be expressed in the left and right of the trunk stream direction.

Out of 94 basins, 37 suggest rightward down-tilt from trunk stream while 57 basins suggest leftward down-tilt. According to the down-tilt direction, 23 basins have northward down-tilt while 27 have eastward, 30 has southward, and the remaining 14 has westward down tilt (Table 1) (Figure 4). Based on the above results, we attribute that all the basins have different down-tilt directions. The $\chi^{2}$ distribution for 94 basins is 8.64, which is more than the critical value of 7.82 at a $95 \%$ confidence level suggesting a bimodal down-tilt direction towards east and south. The $T$ value for 94 basins indicates the mean vector magnitude ranging from $0.15-0.99$ (Figure 5), suggesting that the tilting in the basins is gentle to steep. The vector means of azimuths calculated for all 94 basins indicates 
southward $\left(\theta_{v}=176^{\circ}\right)$ down-tilt (Figure 4), consistent with $A F^{\prime}$ s results, with a high vector magnitude of 0.68 .
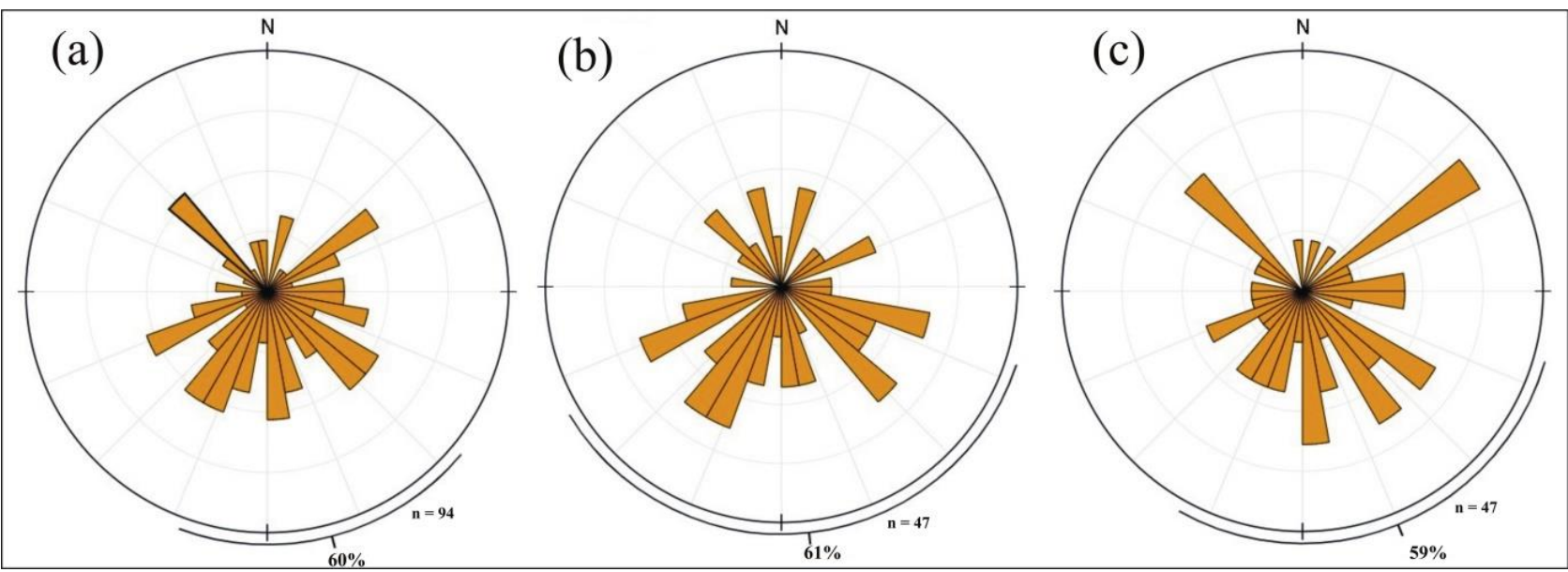

Figure 4. Rose diagram for the mean azimuth of $T$ (a) for the whole Garhwal synform; (b) the northern limb of the synform; (c) the southern limb of the synform. The ' $n$ ' is the number of basins used for analysis; the percentage is the basin percentage coming under the small arc drawn around the periphery; the tiny tick in the outer arch shows the mean azimuth, which very much coincides with the mean azimuth in Figure 5.

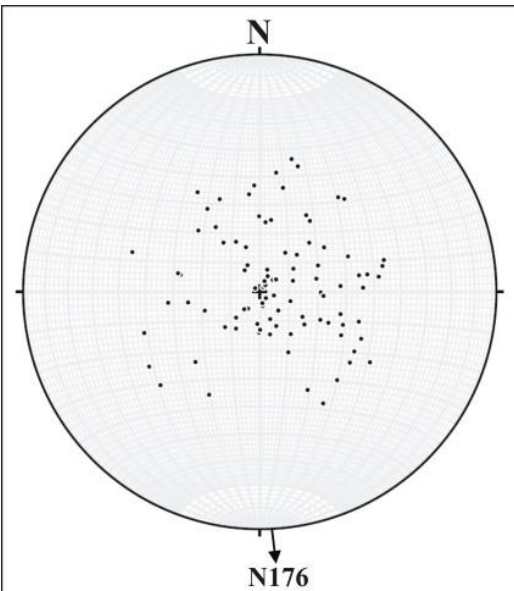

(a)

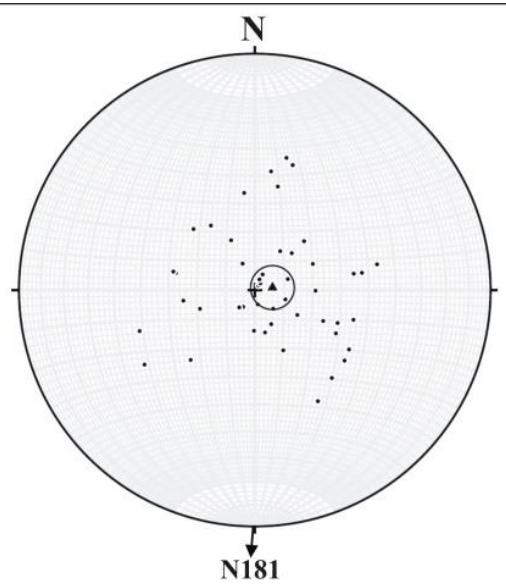

(b)

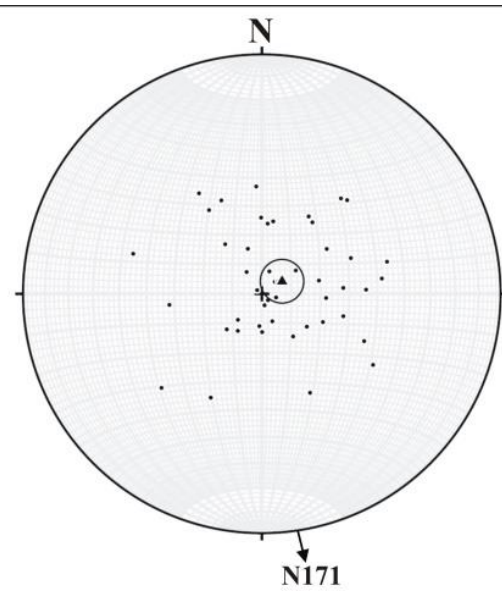

(c)

Figure 5. Stereographic projections of the magnitude and azimuths of $T$ for (a) Garhwal synform; (b) Northern limb of synform; and (c) Southern limb of synform. The polar plot of the all basin azimuth; mean azimuth of all three is shown as a small arrow; the mean of the polar plot (black shaded triangle enclosed within a circle) for northern and southern limb is shown in (b) and (c) respectively. At the center of all three polar plots, the magnitude $=0$, and at margins, the magnitude $=1$.

The calculated vector means of azimuths for $T$ suggests that $60 \%$ of the third order basins are trending southward, which reaffirms our results (Figure 4). The $p$-value calculated is 0.034 , which is less than the upper threshold value of 0.5 , suggesting $\theta_{v}$ is statistically significant and needs to be examined for calculating the down-tilt of the basins. We have divided the 94 basins into two categories considering them two separate tectonic blocks. In the present study, 94 third order basins were selected and grouped into two categories; the first category includes 47 basins lying in the northern region consisting of basins from three rivers viz. Hiyunl, Tal and Rawasan, while the second category also has 47 basins in the southern areas formed by four rivers viz. Khoh, Palain, Malin, and 
Medi Gad (Figure 3). The division is done to ascertain more significant statistical results for the region.

The 47 basins in the northern limb of the synform have $A F$ values ranging from 29.24-49.76 for 17 basins (Table 1 ), suggesting $0.3-20.6 \%$ of the larger area left of the trunk stream, while for 30 basins, it ranges from 51.15-77.26 (Table 1) suggesting 1.15-27.26\% of the larger area falls in right of the trunk stream. Among 47 basins, 13 are down-tilted northerly, 13 are down-tilted easterly, 15 are down-tilted southerly, and 6 are down-tilted westerly (Table 1). The vector magnitude for $T$ ranges from 0.18 to 0.9 (Table 1$)$, suggesting a gentle to steep tilt in the basin (Figure 5$)$, with a vector magnitude $(r)$ value of 0.67 . The mean vector magnitude of the 47 basins azimuth indicates a southward tilt $\left(\theta_{v}=181^{\circ}\right)$. The vector means of azimuths calculated suggests that $61 \%$ of the 47 third order basins are trending towards the south and supports the finding of $\theta_{v}$ (Figure 4). The calculated $\chi^{2}$ value for the 47 basins is 5.619, which is lower than the critical value of 7.81 at $95 \%$ confidence level, suggesting it fails to reject the null hypothesis and there is the relationship between basin tilt direction and its position in the left and right flank of the main river basin. The calculated $p$-value for the northern limb basins is 0.1317 , which is lower than the threshold values of 0.5 , suggesting a statistical significance of computed $\theta_{v}$.

The southern limb of the Garhwal synform also includes 47 basins lying in four river basins. The southern limb of the synform has $A F$ value ranging from 20.33-49.97 (Table 1) for 21 basins suggesting $0.3-29.7 \%$ of the larger area left of the trunk stream, while for the remaining 26 basins, it ranges from 50.34-75.72 (Table 1) suggesting $0.34-25.72 \%$ of the larger area falls in right of the trunk stream. Among 47 basins, 10 are down-tilted northerly, 14 are down-tilted easterly, 15 are down-tilted southerly, and 8 are down-tilted westerly (Table 1). The calculated $\chi^{2}$ value for the 47 basins is 5.776, which is lower than the critical value of 7.81 at $95 \%$ confidence level, suggesting it fails to reject the null hypothesis and there is the relationship between basin tilt direction and its position in the left and right flank of the main river basin. The vector magnitude for $T$ ranges from 0.15 to 0.99 (Figure 5), suggesting a gentle to steep tilt in the basin, with a vector magnitude $(r)$ value of 0.70 . The mean vector magnitude of the 47 basins azimuth indicates a southward tilt $\left(\theta_{v}=171^{\circ}\right)$. The calculated vector means of azimuths suggests that $59 \%$ of the 47 third order basins are trending towards the south and supports the hypothesis of southward migration of third order basin down-tilt (Figure 4). The calculated $p$-value for the northern limb basins is 0.123 , which is lower than the threshold values of 0.5 , suggesting a statistical significance of computed $\theta_{v}$.

\section{Discussion}

The NW-SE trending Garhwal synform in Lesser Himalaya is formed due to the migration or transport of metamorphic rocks from Higher Himalaya as a result of regionalscale tectonic activity during Eocene-Oligocene [13,51,52]. The whole Himalayan orogen is uplifting continuously [2], and most of the deformational activity is accommodated in the region between HFT and MCT. The study area is tectonically active and uplifting at a steady rate due to convergence of Indo and Eurasian plates [52] leading to down-tilting of the basins. The Garhwal synform, as a consequence, is uplifting due to convergence activity along with the Garhwal thrust (GT), HFT, and MBT, and several other mesoscale faults and thrusts, viz. Amri thrust (AT), Lansdowne thrust (LT), Medi gad fault etc. (Figure 1). The tectonically active status of the GT and the AT is yet to be established, but the geomorphic analysis suggests an active status of these structural entities. The HFT and MBT in the region are seismically active and uplifting at a constant annual rate of $10-15 \mathrm{~mm} /$ year [2] The Garhwal synform is categorized as pop-up klippen [24], which suggests it is formed as a result of the coupled effect of simple shear and lateral shortening [53].

The investigation of third order basins in the Garhwal synform has shown that in the majority of basins, the azimuth of $T$ migrates to different sides of the midline (Figure 3 ). Therefore, the basin down-tilt directions as presented by $A F$ is not always confirmed by the azimuth of $T$. Similar studies in comparable structural setup was carried out by 
earlier authors $[6,54]$ in the southern part of the Himalaya of Uttarakhand has suggested considering either $\mathrm{AF}$ or $\mathrm{T}$ as baseline data and analyze using statistical methodologies to support or refine the results. In the present study, admittedly, the results have shown a similar pattern of down-tilt direction as observed in earlier reports [6,13]; therefore, the $T$ azimuth data is taken as the baseline data to support the logic that it deals with the development and growth of drainage basins. The evidence from statistical analysis has also shown variation in direction of down-tilt direction in basins as seen in Figure 3, is possibly due to the polyphase deformation in the Garhwal synform [19-24,36]. Other possible reasons for the variation in down-tilt direction could be attributed to the presence of several mesoscale faults and thrust like Medi Gad fault, Dugadda fault, AT, GT etc.; also the presence of major regional thrusts like MBT, HFT, and ST.

More accurate and sophisticated satellite or aerial images are available for terrain analysis and modeling in recent years. Remote sensing coupled with GIS is used to assess geomorphic indices to confirm the active tectonics in a tectonically active terrain [55]. Several DEMs provided freely by various agencies all around the globe allow assessing the tectonic activities remotely from any part of the world. The DEM provided by these agencies has varied spatial resolution. Therefore, the results calculated for various geomorphic indices may vary depending upon the DEM type used for the study [55]. The satellite data used in the present study is SRTM30 DEM, which is an adequate DEM to calculate tectonic index in lower elevation in Himalayan terrain [56]. The DEM used proved to be efficient for calculating tectonic indexes and is accurate enough to analyze the tectonic geomorphology of the drainage network draining the fault blocks in the Garhwal synform [55].

In the present study, the calculated $A F$ and $T$ ascertain that downward tilt is predominantly southward (Figure 4). The $A F$ and $T$ for 96 basins indicate a southward down-tilt (Figure 3) that is reaffirmed by calculating these factors for northward and southward limbs (Table 1) of the Garhwal synformal region (Figure 4). The basin tilt direction implies that the tectonic blocks in the area exhibit a unidirectional regional uplift (Figure 4). The tilting of the northern and southern limb also suggests that it is controlled by regional tectonic activities related to GT, AT, MBT, and HFT. The geomorphic indices and statistical analysis suggest reverse faulting in the region. The overall geometry and pattern of third order basins in the Garhwal synform indicate that the propagation of the Lesser Himalaya tectonic block is predominantly southward.

The statistical analysis of the results indicates the significance of $A F$ and $T$ to ascertain the active tectonic tilting. The statistical analysis revealed that the null hypothesis of basin azimuth migration is also valid when observing in both the limbs of river basins. The overall hypothesis for the active tectonics in Garhwal synform suggests that the faster rate of movement by Indian plate has potentially resulted in rapid uplift of frontal part and southward migration of basins. The rapid migration of basin streams can be ascertained by the high $T$ values (Table 1), which signify prolonged tectonic activities operational in these basins resulting in steep inclination. In contrast, a basin with lower values suggests an early stage of development and low inclination. In Garhwal synform, it is proposed that the dip of the rock beds does not impact the basin tilt; third order basins in both northern and southern limb are following the regional tectonics and showing similar migration trends suggesting regional dominance of tectonics over the smaller litho-units. In the Himalayan terrain, it is difficult to identify these active tectonic zones. Also, it is not always feasible to complete a detailed geomorphological and geological study as the region is almost devoid of any exposed fault scarps; further, ongoing denudational and erosional processes remove signatures of fault scarps. However, the present study provides significant information about the impact of regional structure on the active tectonics and geomorphology of the Garhwal synform. 


\section{Conclusions}

The present study attempts to assess active tectonics operational in the Garhwal synformal region by evaluating tilted blocks using geomorphic indices. The key findings of the study are:

a Regional and local thrusts govern the basin tilting. The variation in basin down-tilt indicates polyphase deformation and control of local faults in the basin development.

b The results after computing $A F$ and $T$ suggests tectonic blocks in the Garhwal synform are rapidly uplifting. The Main Boundary Thrust hanging wall is migrating towards the south due to the migration of the basin and its steep inclination.

c The quantitative and statistical analyses of $T$ and $A F$ infer that the tectonic movement in the region is unidirectional, i.e., towards the South.

d It is plausible that the hinge of the synform is experiencing compressional stresses, and the syncline is shrinking due to southward movement of the Garhwal synform tectonic block and northward movement of the Indian plate.

e The hydrological characteristics are affected by active tectonics, and basin tilting has resulted in lengthening drainages.

$\mathrm{f}$ The geomorphic indices used in this study are the requisite tools in ascertaining the role of active tectonics in crustal deformation.

g The study suggests that SRTM30 DEM used in this study is adequate to derive active tectonics by analyzing geomorphic indices in the lower elevations of the Himalayan terrain.

$\mathrm{h}$ The statistical analysis supports the null hypothesis of basin migration in both flanks of the river.

Author Contributions: A.R. and S.B. conceived the project and did the field work; A.R. did the calculations and data analysis; S.B. and Y.S. interpreted the results and provided geological knowledge of the Garhwal synform; A.R., S.B. and Y.S. have contributed in manuscript writing. All authors have read and agreed to the submitted version of the manuscript.

Funding: This research was funded by the Institute of Eminence (IoE) research grant, BHU (Dev. Scheme No. 6031).

Institutional Review Board Statement: Not applicable.

Informed Consent Statement: Not applicable.

Data Availability Statement: The data used is available in the manuscript.

Acknowledgments: This study is a part of the work of A.R. The authors are thankful to the Head, Department of Geology, Hemvati Nandan Bahuguna Garhwal University, for the necessary permissions and logistic assistance during the present work; authors are also thankful to the Department of Geology, Banaras Hindu University for their continuous assistance during the research work. Authors are also very grateful to the research scholar Department of Geology, Hemvati Nandan Bahuguna Garhwal University and LAMP, Department of Geology, Banaras Hindu University for their assistance. The authors are also thankful to the anonymous reviewers for their valuable suggestions, which improved the quality of the manuscript.

Conflicts of Interest: The authors declare no conflict of interest.

\section{References}

1. Robinson, D.M.; Pearson, O.N. Was Himalayan normal faulting triggered by initiation of the Ramgarh-Munsiari thrust and development of the Lesser Himalayan duplex? Int. J. Earth Sci. 2013, 102, 1773-1790. [CrossRef]

2. Thakur, V.C. Active tectonics of Himalayan Frontal Thrust and Seismic Hazard to Ganga Plain. Curr. Sci. 2004, 86, 1554-1560.

3. Parkash, B.; Rathor, R.S.; Pati, P.; Jakhmola, R.P.; Singh, S. Convergence rates along the Himalayan Frontal Thrust inferred from terraces at Chandi devi Temple Hill, Haridwar, Northwestern Himalaya. Curr. Sci. 2011, 100, 1426-1432.

4. Ponraj, M.; Miura, S.; Reddy, C.D.; Prajapati, S.K.; Amirtharaj, S.; Mahajan, S.H. Estimation of strain distribution using GPS measurements in the Kumaun region of Lesser Himalaya. J. Asian Earth Sci. 2010, 39, 658-667. [CrossRef]

5. Cox, R.T.; Van Arsdale, R.B.; Harris, J.B. Identification of possible Quaternary deformation in the north-eastern Mississippi Embayment using quantitative geomorphic analysis of drainage-basin asymmetry. Geol. Soc. Am. Bull. 2001, 113, 615-624. 
6. Goswami, P.K.; Deopa, T. Quaternary block-tilting in southern Himalayan ranges of eastern Uttarakhand, India. Z. Geomorphol. 2012, 57, 45-60. [CrossRef]

7. Ibanez, D.M.; Riccomini, C.; Miranda, F.P. Geomorphological evidence of recent tilting in the Central Amazonia Region. Geomorphology 2014, 214, 378-387. [CrossRef]

8. Valdiya, K.S.; Narayana, A.C. River response to neotectonic activity: Example from Kerala, India. J. Geol. Soc. India 2007, 70, 427-443.

9. Burbank, D.W.; Anderson, R.S. Tectonic Geomorphology, 2nd ed.; Wiley-Blackwell: Hoboken, NJ, USA, 2011; p. 454. [CrossRef]

10. Keller, E.A.; Pinter, N. Active Tectonics: Earthquakes, Uplift, and Landscape, 2nd ed.; Prentice Hall: Upper Saddle River, NJ, USA, 2002.

11. Azor, A.; Keller, E.A.; Yeats, R.S. Geomorphic indicators of active fold growth: South mountain-Oak Ridge anticline, Ventura basin, southern California. Geol. Soc. Am. Bull. 2002, 114, 745-753. [CrossRef]

12. Kotlia, B.S.; Goswami, P.K.; Joshi, L.M.; Singh, A.K.; Sharma, A.K. Sedimentary environment and geomorphic development of the Uppermost Siwalik molasse in Kumaun Himalayan foreland basin, North India. Geol. J. 2018, 53, 159-177. [CrossRef]

13. Goswami, P.K.; Pant, S. Active bidirectional tectonic-tilting in a part of the Almora Klippe, Kumaun Lesser Himalaya, India: Insights from statistical analyses of geomorphic indices. Quat. Int. 2019, 523, 46-53. [CrossRef]

14. Hoolbrook, J.; Schumm, S.A. Geomorphic and sedimentary response of rivers to tectonic deformation: A brief review and critique of a tool for recognizing subtle epeirogenic deformation in modern and ancient settings. Tectonophy 1999, 305, 287-306. [CrossRef]

15. Sreedevi, P.D.; Subrahmanyam, K.; Ahmed, S. Integrated approach for delineating potential zones to explore for groundwater in the Pageru River basin, Cuddapah District, Andhra Pradesh, India. Hyd. J. 2005, 13, 534-545. [CrossRef]

16. Lahiri, S.K.; Sinha, R. Tectonic controls on themorphodynamics of the Brahmaputra River system in the upper Assam valley, India. Geomorphology 2012, 169-170, 74-85. [CrossRef]

17. Rawat, A.; Bisht, M.P.S.; Sundriyal, Y.P.; Banerjee, S.; Singh, V. Assessment of soil erosion, flood risk and groundwater potential of Dhanari watershed using remote sensing and geographic information system, district Uttarkashi, Uttarakhand, India. Appl. Water Sci. 2021, 11, 119. [CrossRef]

18. Jiang, G.; Christie-Blick, N.; Kaufman, A.; Banerjee, D.M.; Rai, V. Sequence Stratigraphy of the Neoproterozoic Infra Krol Formation and Krol Group, Lesser Himalaya, India. J. Sediment. Res. 2002, 72, 524-542. [CrossRef]

19. Shanker, R.; Ganesan, T.M. A note on the Garhwal Nappe. Himal. Geol. 1973, 3, 241-258.

20. Gupta, L.N. A Contribution to the Geology of the Lansdowne area, Garhwal Himalayas, India. J. Geol. Soc. Ind. 1976, 17, 449-460.

21. Gupta, L.N. Abnormal tectonics of the allochthonous Lansdowne granite and the tectonic history of Garhwal nappe. Indian Miner. 1976, 17, 73-85.

22. Sarkar, S.N.; Dutta, S.M. Structural Analysis of a Part of the Folded Garhwal Nappe Around Lansdowne, UP; Miscellaneous PublicationGeological Survey of India: Calcutta, India, 1982; Volume 41, pp. 241-258.

23. Gairola, V.K. Structure and tectonics of Garhwal Synform. In The Himalayan Orogen and Global Tectonics; Oxford and IBH Publishing: New Delhi, India, 1992; pp. 89-104.

24. Devrani, U.; Dubey, A.K. Anisotropy of magnetic susceptibility and petrofabric studies in the Garhwal synform, Outer Lesser Himalaya: Evidence of pop-up klippen. Island Arc 2008, 18, 428-443. [CrossRef]

25. Valdiya, K.S. Geology of Kumaun Lesser Himalaya; Wadia Institute of Himalayan Geology: Dehradun, India, 1980.

26. Valdiya, K.S. The Making of India: Geodynamic Evolution; Springer International Publishing: Cham, Switzerland, 2016.

27. Gansser, A. Geology of the Himalayas; Interscience Publishers: London, UK, 1964.

28. Banerjee, S.; Srivastava, H.B. Tectonic Implications of Small-Scale Structures in the Main Central Thrust Zone of Garhwal Higher Himalaya. In Structural Geometry of Mobile Belts of the Indian Subcontinent; Springer: Cham, Switzerland, 2020; pp. $213-232$. [CrossRef]

29. Fuchs, G.; Sinha, A.K. The tectonics of the Garhwal-Kumaun lesser Himalaya. Jahrb. Geol. Bundesanst. 1978, 121, $219-241$.

30. Valdiya, K.S. Geological Map of Kumaun Lesser Himalaya; Wadia Institute of Himalayan Geology: Dehradun, India, 2008.

31. Middlemiss, C.S. Crystalline and metamorphic rocks of the Lower Himalaya, Garhwal and Kumaun. Rec. Geol. Surv. India 1887, 20, 134-143.

32. Auden, J.B. Structure of the Himalaya in Garhwal. Rec. Geol. Surv. India 1937, 71, 407-433.

33. Auden, J.B. Traverses in the Himalayas. Rec. Geol. Surv. India 1939, 69, 123-167.

34. Heim, A.; Gansser, A. Central Himalaya-Geological observations of Swiss Expedition. Memoirés de la Société Helvétique des Sciences Naturelles 1939, 73, 1-245.

35. Asthana, A.K.L. Landform evolution of the Nayar basin Garhwal Himalaya, Uttarakhand. Himalayan Geol. 2012, 33, 71-82.

36. Maity, S.; Banerjee, S. Structural Architecture of Lansdowne Klippe in the Lansdowne Area: An Insight from Microstructural and AMS Studies. Master's Thesis, Banaras Hindu University, Varanasi, India, 2018.

37. Osborn, G.; du Toit, C. Lateral planation of rivers as a geomorphic agent. Geomorphology 1991, 4, 249-260. [CrossRef]

38. Alexander, J.; Leeder, M.R. Geomorphology and surface tilting in an active extensional basin, SW Montana, USA. J. Geol. Soc. Lond. 1990, 147, 461-467. [CrossRef]

39. Garrote, J.; Heydt, G.G.; Cox, R.T. Multi-stream order analyses in basin asymmetry: A tool to discriminate the influence of neotectonics in fluvial landscape development (Madrid Basin, Central Spain). Geomorphology 2008, 102, 130-144. [CrossRef] 
40. Perez-Pena, J.V.; Azor, A.; Azanon, J.M.; Keller, E.A. Active tectonics in the Sierra Nevada (Betic Cordillera, SE Spain): Insights from geomorphic indexes and drainage pattern analysis. Geomorphology 2010, 119, 74-87. [CrossRef]

41. Agarwal, K.K.; Sharma, V.K. Quaternary tilt-block tectonics in parts of eastern Kumaun Himalaya, India. Z. Geomorphol. 2011, 55, 197-208. [CrossRef]

42. Daxberger, H.; Riller, U. Analysis of geomorphic indices in the southern central Andes $\left(23^{\circ}-28^{\circ} \mathrm{S}\right)$ : Evidence for pervasive quaternary to recent deformation in the puna plateau. Geomorphology 2015, 248, 57-76. [CrossRef]

43. Gaidzik, K.; Ramirez-Herrera, M.T. Geomorphic indices and relative tectonic uplift in the Guerrero sector of the Mexican forearc. Geoscience Front. 2017, 8, 885-902. [CrossRef]

44. Horton, R.E. Erosional development of streams and their drainage basins-hydrophysical approach to quantitative morphology. Geol. Soc. Am. Bull. 1945, 56, 275-370. [CrossRef]

45. Hare, P.W.; Gardner, T.W. Geomorphic indicators of vertical neotectonism along converging plate margins, Nicoya Peninsula, Costa Rica. In Proceedings of the 15th Geomorphology Symposium; Allen and Unwin: Boston, MA, USA, September 1985; pp. 76-104.

46. Keller, E.A.; Pinter, N. Active Tectonics, Earthquake Uplift and Landscape; Prentice Hall: Upper Saddle River, NJ, USA, 1996.

47. Davis, J.C. Statistics and Data Analysis in Geology; John Wiley \& Sons: Singapore, 2002; p. 639.

48. Cox, R.T. Analysis of drainage-basin symmetry as a rapid technique to identify areas of possible Quaternary tilt-block tectonics: An example from the Mississippi Embayment. Geol. Soc. Am. Bull. 1994, 106, 571-581. [CrossRef]

49. Sharma, G.; Ray, P.K.C.; Mohanty, S. Morphotectonic analysis and GNSS observations for assessment of relative tectonic activity in Alaknanda basin of Garhwal Himalaya, India. Geomorphology 2018, 301, 108-120. [CrossRef]

50. Curray, J.R. The analysis of two-dimensional orientation data. J. Geol. 1956, 64, 117-131. [CrossRef]

51. Ahmad, T.; Harris, N.; Bickle, M.; Chapman, H.; Bunbury, J.; Prince, C. Isotopic constraints on the structural relationships between the Lesser Himalayan Series and the High Himalayan Crystalline Series, Garhwal Himalaya. Geol. Soc. Am. Bull. 2000, 112, 467-477. [CrossRef]

52. DeCelles, P.G.; Robinson, D.M.; Quade, J.; Ojha, T.P.; Garzione, C.N.; Copeland, P.; Upreti, B.N. Stratigraphy, structure, and tectonic evolution of the Himalayan fold-thrust belt in western Nepal. Tectonics 2001, 20, 487-509. [CrossRef]

53. Jayangondaperumal, R.; Dubey, A.K. Superposed folding of a blind thrust and formation of klippen: Results of anisotropic magnetic susceptibility studies from the Lesser Himalaya. J. Asian Earth Sci. 2001, 19, 713-725. [CrossRef]

54. Goswami, P.K.; Kshetrimayum, A.S. Pattern of active tectonic deformation across the Churachandpur-Mao thrust zone of Manipur Hills, Indo-Myanmar range, NE India: Inferences from geomorphic features and indices. Quat. Int. 2020, 553, 144-158. [CrossRef]

55. Koukouvelas1, I.K.; Zygouri1, V.; Nikolakopoulos, K.; Verroios, S. Treatise on the tectonic geomorphology of active faults: The significance of using a universal global digital elevation model. J. Struct. Geol. 2018, 116, 241-252. [CrossRef]

56. Mukul, M.; Mukul, M. Uncertainties in Digital Elevation Models from Global Advanced Land Observing Satellite (ALOS) digital topography data in the Indian subcontinent. J. Earth Syst. Sci. 2021, 130, 51. [CrossRef] 